\title{
DISTANCE FORMS OF CRISIS INTERVENTION DURING THE COVID-19 PANDEMIC
}

\author{
Anna Masariková ${ }^{1}$, Daniel Markovič $^{2}$, Soňa Šrobárová ${ }^{3}$
}

\begin{abstract}
In the current pandemic period caused by COVID-19, the availability of distance forms of social services is exceedingly important. Crisis intervention performed in a distance format helps a person experiencing an acute crisis via telephone and online form of assistance. The paper's primary aim was to find out the use of distance crisis intervention services during the COVID-19 pandemic in Slovakia, to clarify what needs are prioritized for respondents at this time, the type of social problems they turn to crisis intervention and the usability of crisis lines during the pandemic. The quantitative survey was carried out in the form of an anonymous questionnaire, which was available only in electronic form via Google forms, and the respondents were addressed on social networks. The questionnaire was filled in by 291 respondents. Based on the processed data, the distance form of assistance is a little-sought option in solving social problems related to the COVID19 pandemic. Our recommendation is to support and promote the distance form of assistance more through advertising or financial support - especially considering that many crises could not be dealt with on the part of respondents or the helplines themselves.
\end{abstract}

UDC Classification: 304, DOI: https://doi.org/10.12955/pss.v2.231

Keywords: crisis intervention, distance form of crisis intervention, social problems, crisis.

\section{Introduction}

In connection with the current situation regarding the spread of the novel coronavirus COVID-19, we are briefed daily by reports of new confirmed cases, deaths, and measures taken. In a pandemic, we are not just fighting the virus, but we are trying to control and manage fear, stigma, and discrimination and solve various kinds of social problems. Under certain life circumstances, every person may experience destabilization at a psychological as well as social level. A frequent crisis trigger is initiated by external events such as natural or technological disasters, military conflicts, kidnappings, or city violence. Besides external factors, a crisis may also be due to situations when one's life, home, property or well-being is under threat (Sá et al., 2008). One's experience of crisis may affect their health, such that they begin to exhibit clinical symptoms and hence need external assistance (Silva et al., 2015). In such situations, quick, suitable and accessible professional help is important. One such solution is the provision of crisis aid, which, in Slovakia, is regulated in the Law on social services, which as social help regards a "social service provided to an individual in a socially critical situation or in a difficult life situation which one cannot resolve by themselves and is provided especially via social counselling" (Law no. 448/2008 Coll SR of 30 October 2008 on social services, § 53).

Under current circumstances, when people are in self-isolation so as to limit the spread of COVID-19, we observe the growing importance of the use of distance forms of crisis assistance provided via telecommunication technologies such as telephone or the internet. Of particular significance is online accessibility.

The primary goal of the research carried out in May 2020 was to find the use of distance crisis intervention services, the type of social problems with which they turn to the crisis intervention and the knowledge of the types of crisis lines.

\section{Literature Review}

What is left to be answered is whether their importance grows due to the growth of socially pathological phenomena and social situations in one's life during the pandemic. The question remains whether their importance is also growing in terms of the growth of socio-pathological phenomena and social situations in human life during a pandemic. With the arrival of the coronavirus in the Slovak Republic, a large number of people found themselves in a situation they face for the first time, which also brings with it many losses, difficult situations and stressful moments full of uncertainty. The Crisis Helpline was established during the COVID-19 pandemic as an initiative of the civic association IPčko with the aim of providing psychological help to people in crisis. Statistics show that in the same time period, the number of contacts with domestic violence and sexual abuse increased up to threefold in

\footnotetext{
${ }^{1}$ Catholic University in Ruzomberok, Faculty of Education, Ruzomberok, Slovakia, anna.masarikova177@edu.ku.sk

${ }^{2}$ Catholic University in Ruzomberok, Faculty of Education, Ruzomberok, Slovakia, daniel.markovič@ku.sk

${ }^{3}$ Catholic University in Ruzomberok, Faculty of Education, Ruzomberok, Slovakia, sona.srobarova@ku.sk
} 
2019 and 2020. These days, repatriates in state quarantines with feelings of anxiety, helplessness and fear of possible infection are also turning to them for help. Contacts for thoughts of suicide and suicidal tendencies have also increased. IPčko communicates daily with 10-15 people in a suicide crisis who want to end their lives (IPcko, 2021).

A negative aspect pertaining to the current health crisis is a growing number of help lines, which want to respond to the crisis during the pandemic but, unfortunately, without sufficient expert preparation, training, or practice in providing such forms of counselling. At the beginning of 2020, the children's help line witnessed a $90 \%$ increase in young people's interest in the corona virus. Although this help line is primarily aimed at children and youth, even adults called, since, like children, they expressed their worries and fears concerning an unknown situation and its consequence and needed to solve a new type of problems related to the social changes brought by the health crisis (Child Safety Line, 2021). According to Rybanská, the Child Safety Line distance counselling coordinator, this form of counselling differs from the in-person forms of communication-based intervention: "It is a form of communication with the client without personal contact. The decisive factor is the client's anonymity, which we are striving to maintain even by not publicizing their story through media - even in an anonymized form" (Rybanská, personal communication, 2021). There are many differences between crisis intervention and traditional counselling, pertaining to the intervention's purpose, setting, time, and plan (Puleo, Gothlin, 2010).

The Slovak lines could be classified, on the basis of their target group, into helplines for children, youth, adults and elderly. Children and youth are targeted by Linka detskej istoty (Child Safety Line) and Linka detskej dôvery Lienka (trans. Children's trust line "Ladybird"). Within Linka detskej istoty there is a special Linka pre nezvestné a sexuálne zneuživané deti (Line for missing and sexually abused children).Linka detskej istoty also facilitates two advisory services for parents and other adults calling in children's interest: parental counselling and social-legal counselling. Youth aid is the focus of the helpline IPčko- internetová linka dôvery pre mladých l'udí (trans. An internet helpline for young people), which has recently also founded a crisis helpline focused on those experiencing COVID-19related crises. Most widely known help lines for adults and elderly are the following:

- Linka dôvery Nezábudka (trans. Forget-me-not Help line) founded by the Mental Health League;

- Telefónna linka pre ženy zaživajúce násilie a ich deti (trans. Telephone line for women experiencing domestic abuse and their children) founded by the Slovak Women's Alliance;

- Infolinka Hniezdo záchrany (trans. The "rescue nest" info line) aimed at women with unwanted pregnancy;

- Linka pomoci pre závislých od alkoholu a drog (trans. Helpline for people addicted to alcohol and drugs);

- Linka pomoci AIDS (trans. AIDS help line);

- Infolinka Alzheimerovej choroby (trans. Alzheimer's disease help line);

- Linka dôvery na prevenciu v oblasti siekt (trans. Help line for prevention regarding occult sects);

- Senior linka (trans. Help line for the elderly) founded by the NGO Fórum pre pomoc staršim (trans. Forum for helping elderly), etc.

Social workers have an important role to play in addressing the physical, mental and, in particular, social consequences of the Covid-19 pandemic (Bright, 2020).

\section{Methodology}

In order for distance forms of crisis intervention to effectively help solve people's problems, it is extremely important whether they are known among people. We carried out the quantitative survey in the form of an anonymous questionnaire, which was available only in electronic form via the Google forms, and the respondents were addressed on social networks. The questionnaire was filled in by 291 respondents from Slovakia. We gradually evaluated the answers we received from the respondents through an electronic questionnaire descriptively as well as using the SPSS program. Of the total number of 291 respondents, $88 \%$ are women, and 12\% are men, which means 251 women and 41 men. According to the age of the respondents, we divided the age scale into five groups. The most numerous group consisted of respondents aged 36-45 years, and the second most numerous group were 
respondents aged 46-55 years. The respondents come from the city in the number of 154, which is $46 \%$, and from the village, $44 \%$, is 121 respondents. We set the following research questions:

Research question 1: Is there a difference between the respondents' social problems in men and women at the time of the COVID-19 pandemic?

Research question 2: Is there a difference in respondents' needs between men and women at the time of the COVID-19 pandemic?

Research question 3: Which lines of the distance form of crisis intervention did the respondents use during the COVID pandemic?

Questions RQ1-RQ3 surveyed respondents about the use of distance crisis intervention services; types of social problems during the COVID-19 pandemic, and a distance form of crisis intervention during the COVID pandemic.

\section{Results}

RQ1: Is there a difference between the respondents' social problems in men and women at the time of the COVID pandemic?

We asked respondents in the form of a closed question about their most pressing problem during the COVID19 pandemic. We categorized the answers into sixteen groups.

\begin{tabular}{|c|c|c|c|c|c|c|c|c|c|}
\hline \multirow{2}{*}{ Variables } & \multicolumn{3}{|l|}{ Men } & \multicolumn{3}{|c|}{ Women } & \multicolumn{3}{|c|}{ Total } \\
\hline & $\mathbf{M}$ & $\mathbf{N}$ & SD & $\mathbf{M}$ & $\mathbf{N}$ & SD & $\mathbf{M}$ & $\mathbf{N}$ & SD \\
\hline Deterioration of health & 0.21 & 29 & 0.62 & 0.21 & 244 & 0.58 & 0.21 & 273 & 0.59 \\
\hline Increase in aggression & 0.34 & 29 & 0.72 & 0.40 & 244 & 0.74 & 0.40 & 273 & 0.74 \\
\hline An increase in fear for oneself & 0.34 & 29 & 0.77 & 0.55 & 244 & 0.84 & 0.53 & 273 & 0.84 \\
\hline More sadness & 0.59 & 29 & 0.87 & 0.77 & 244 & 0.93 & 0.75 & 273 & 0.93 \\
\hline An increase in hopelessness & 0.21 & 29 & 0.49 & 0.39 & 244 & 0.73 & 0.37 & 273 & 0.71 \\
\hline An increase in fear for your family & 1.28 & 29 & 0.96 & 1.31 & 244 & 0.91 & 1.31 & 273 & 0.91 \\
\hline Fear of living & 0.93 & 29 & 0.88 & 0.84 & 244 & 0.94 & 0.85 & 273 & 0.94 \\
\hline Increased feeling of loneliness & 0.48 & 29 & 0.87 & 0.55 & 244 & 0.86 & 0.55 & 273 & 0.86 \\
\hline Increased feeling of isolation & 0.59 & 29 & 0.91 & 0.93 & 244 & 0.97 & 0.89 & 273 & 0.97 \\
\hline $\begin{array}{l}\text { An increase in the feeling of } \\
\text { unhappiness }\end{array}$ & 0.28 & 29 & 0.65 & 0.35 & 244 & 0.70 & 0.34 & 273 & 0.70 \\
\hline Loss of certainty & 0.69 & 29 & 0.89 & 0.68 & 244 & 0.88 & 0.68 & 273 & 0.88 \\
\hline Fear of illness of a family member & 1.21 & 29 & 0.98 & 1.45 & 244 & 0.88 & 1.42 & 273 & 0.89 \\
\hline Fear of financial security & 1.14 & 29 & 0.92 & 1.11 & 244 & 0.95 & 1.11 & 273 & 0.94 \\
\hline $\begin{array}{l}\text { Greater fear of the death of a loved } \\
\text { one }\end{array}$ & 1.17 & 29 & 1.00 & 1.14 & 244 & 0.96 & 1.14 & 273 & 0.96 \\
\hline $\begin{array}{l}\text { Change in eating habits (more or } \\
\text { less food) }\end{array}$ & 0.48 & 29 & 0.87 & 0.63 & 244 & 0.90 & 0.62 & 273 & 0.89 \\
\hline Change in sleep mode & 0.48 & 29 & 0.87 & 0.55 & 244 & 0.88 & 0.54 & 273 & 0.87 \\
\hline
\end{tabular}

There is no statistically significant difference in these variables between men and women. A higher M score represents a larger measure of the variable. Out of 291 respondents, up to 273 mentioned the most pressing problems afflicting them during the COVID-19 pandemic. Respondents could choose more than one answer. According to Table 1, it can be stated that the increase in family fear, which was started by 29 men, $11 \%$, and 244 women, which is $89 \%$, agreed with the most. The fear of illness of a family member was also reported by 29 men, $11 \%$ and 244 women, which is $89 \%$. Respondents are least bothered by the problem with statement 1 , namely the deterioration of health.

RQ2: Is there a difference in respondents' needs between men and women at the time of the COVID-19 pandemic?

We were interested in how the respondents perceive the needs during the COVID-19 pandemic and their priorities. In addition, whether a significant share in the individual needs of men and women is demonstrated.

For most respondents, 29 men and 244 women, physiological and psychological needs are given priority over social needs ( 242 women and $28 \mathrm{men}$ ). A significant value is the value of the average or 


\begin{tabular}{|c|c|c|c|c|c|}
\hline \multicolumn{2}{|l|}{ Variables } & $\mathbf{N}$ & Mean Rank & $\mathbf{U}$ & $\bar{p}$ \\
\hline \multirow{2}{*}{ Deterioration of health } & Men & 29 & 134.64 & \multirow{2}{*}{3469.5} & \multirow{2}{*}{0.766} \\
\hline & Women & 244 & 137.28 & & \\
\hline \multirow{2}{*}{ Increase in aggression } & Men & 29 & 132.12 & \multirow{2}{*}{3396.5} & \multirow{2}{*}{0.640} \\
\hline & Women & 244 & 137.58 & & \\
\hline \multirow{2}{*}{ An increase in fear for oneself } & Men & 29 & 120.93 & \multirow{2}{*}{3072.0} & \multirow{2}{*}{0.151} \\
\hline & Women & 244 & 138.91 & & \\
\hline \multirow{2}{*}{ More sadness } & Men & 29 & 125.14 & \multirow{2}{*}{3194.0} & \multirow{2}{*}{0.328} \\
\hline & Women & 244 & 138.41 & & \\
\hline \multirow{2}{*}{ An increase in hopelessness } & Men & 29 & 126.05 & \multirow{2}{*}{3220.5} & \multirow{2}{*}{0.289} \\
\hline & Women & 244 & 138.30 & & \\
\hline \multirow{2}{*}{ An increase in fear for your family } & Men & 29 & 135.55 & \multirow{2}{*}{3496.0} & \multirow{2}{*}{0.903} \\
\hline & Women & 244 & 137.17 & & \\
\hline \multirow{2}{*}{ Fear of living } & Men & 29 & 144.21 & \multirow{2}{*}{3329.0} & \multirow{2}{*}{0.562} \\
\hline & Women & 244 & 136.14 & & \\
\hline \multirow{2}{*}{ Increased feeling of loneliness } & Men & 29 & 130.50 & \multirow{2}{*}{3349.5} & \multirow{2}{*}{0.560} \\
\hline & Women & 244 & 137.77 & & \\
\hline \multirow{2}{*}{ Increased feeling of isolation } & Men & 29 & 114.60 & \multirow{2}{*}{2888.5} & \multirow{2}{*}{0.068} \\
\hline & Women & 244 & 139.66 & & \\
\hline \multirow{2}{*}{$\begin{array}{l}\text { An increase in the feeling of } \\
\text { unhappiness }\end{array}$} & Men & 29 & 131.07 & \multirow{2}{*}{3366.0} & \\
\hline & Women & 244 & 137.70 & & 0.551 \\
\hline & Men & 29 & 137.57 & 35215 & $0062+2$ \\
\hline Loss of certainty & Women & 244 & 136.93 & 3521.5 & 0.903 \\
\hline Fear of illnecs of a family member & Men & 29 & 121.79 & & 0171 \\
\hline F ear of iliness or a ramily member & Women & 244 & 138.81 & 3091.0 & $0.1 / 1$ \\
\hline & Men & 29 & 138.55 & 31020 & 0001 \\
\hline Fear of imancial security & Women & 244 & 136.82 & 3493.0 & 0.901 \\
\hline & Men & 29 & 139.71 & & 0825 \\
\hline Greater fear of the death of a loved one & Women & 244 & 136.68 & 3459.5 & 0.825 \\
\hline Change in eating habits (more or less & Men & 29 & 125.88 & & \\
\hline food) & Women & 244 & 138.32 & 3215.5 & 0.333 \\
\hline Change in sleen mode & Men & 29 & 131.91 & 33005 & 0641 \\
\hline Cnange in sleep mode & Women & 244 & 137.60 & 3590.5 & 0.041 \\
\hline
\end{tabular}

\begin{tabular}{|c|c|c|c|c|c|c|c|c|c|}
\hline \multirow{2}{*}{ Gender } & \multicolumn{3}{|c|}{ Men } & \multicolumn{3}{|c|}{ Women } & \multicolumn{3}{|l|}{ Total } \\
\hline & M & $\mathbf{N}$ & SD & $\mathbf{M}$ & $\mathbf{N}$ & SD & M & $\mathbf{N}$ & SD \\
\hline $\begin{array}{l}\text { How important are physiological } \\
\text { needs for you during a pandemic? - } \\
\text { breathing, sleep, nutrition etc. }\end{array}$ & 4.10 & 29 & 1.05 & 4.63 & 244 & 0.77 & 4.58 & 273 & 0.82 \\
\hline $\begin{array}{l}\text { How important are mental needs } \\
\text { for you during a pandemic - love, } \\
\text { happiness, cognition etc. }\end{array}$ & 4.34 & 29 & 0.90 & 4.74 & 244 & 0.73 & 4.70 & 273 & 0.76 \\
\hline $\begin{array}{l}\text { How important are social needs for } \\
\text { you during a pandemic - a feeling } \\
\text { of security and safety, } \\
\text { communication etc. }\end{array}$ & 3.21 & 28 & 1.60 & 3.15 & 242 & 1.90 & 3.16 & 270 & 1.87 \\
\hline
\end{tabular}

$\mathrm{M}$, based on which we can compare the degree of a particular variable in each group. We can already state that there is a difference, e.g. M values in the second variable between men and women differ by approx. 0.4 points. Which is quite a big difference on a scale from 1-5 (Table 4). We evaluated this research question based on the inference table and the Mann-Whitney U test of differences. This test determines whether the difference between the groups is also statistically significant or negligible. The 


\begin{tabular}{|c|c|c|c|c|c|}
\hline \multicolumn{2}{|l|}{ Gender } & \multirow{2}{*}{\begin{tabular}{|l|}
$\mathbf{N}$ \\
29 \\
\end{tabular}} & \multirow{2}{*}{$\begin{array}{l}\text { Mean Rank } \\
100.45\end{array}$} & \multirow{3}{*}{\begin{tabular}{|l|}
$\boldsymbol{U}$ \\
2478.0
\end{tabular}} & \multirow{3}{*}{0.001} \\
\hline \multirow{2}{*}{$\begin{array}{l}\text { How important are physiological needs for you } \\
\text { during a pandemic? - breathing, sleep, } \\
\text { nutrition etc. }\end{array}$} & Men & & & & \\
\hline & Women & 244 & 141.34 & & \\
\hline \multirow{2}{*}{$\begin{array}{l}\text { How important are mental needs for you } \\
\text { during a pandemic - love, happiness, cognition } \\
\text { etc. }\end{array}$} & Men & 29 & 104.78 & \multirow[b]{2}{*}{2603.5} & \multirow[b]{2}{*}{0.000} \\
\hline & Women & 244 & 140.83 & & \\
\hline \multirow{2}{*}{$\begin{array}{l}\text { How important are social needs for you during } \\
\text { a pandemic - a feeling of security and safety, } \\
\text { communication etc. }\end{array}$} & Men & 28 & 133.14 & \multirow[b]{2}{*}{3322.0} & \multirow[b]{2}{*}{0.854} \\
\hline & Women & 242 & 135.77 & & \\
\hline
\end{tabular}

essential indicator is the Mean Rank or the average of the serial numbers, the decisive value is the value of $\mathrm{p}$, on the basis of which we know that the difference is not significant. A statistically significant difference was found between men and women in the first and second variables based on this test. In both variables, women had significantly higher average values.

\section{RQ3: Which lines of the distance form of crisis intervention do the respondents use?}

We asked the RQ3 question in order to find out whether the respondents know the specific lines of help and, if so, which ones. We were also interested in which helplines are among the best known, according to the respondents. Respondents could choose one of the options in the semi-structured question or add a free answer.

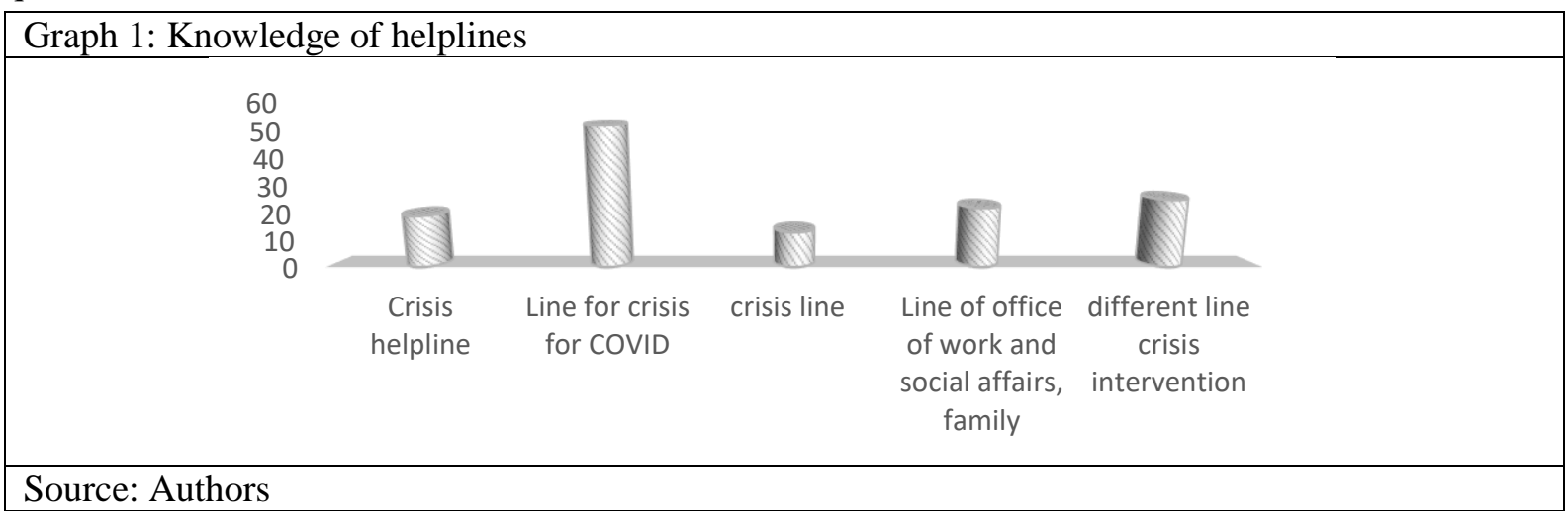

The data shown in Graph 1 show that out of 131 respondents, COVID - related to the provision of information on illness, pandemic measures and assistance during illness - used 52, that is $39 \%$, another crisis line without mentioning 25 (19) respondents, the line of the Office of Social Affairs and the family used by $22(16 \%)$ respondents and $19(14 \%)$ by the crisis helpline.

\section{Discussion}

From the research data obtained and processed, we can conclude that most people from Slovakia deal with social issues during the COVID-19 pandemic. Most of them are concerns about deteriorating health - an increase in fear for the family and fear for a family member's illness. An interesting finding is also the fear of financial security or greater fear of the death of a loved one, or fear of livelihood. Regarding the less significant social problems mentioned by the respondents, the social problems were associated with an increase in hopelessness, an increase in self-esteem or a loss of security. Respondents characterized which needs are needed for them within the pandemic. Based on the results, it can be stated that both men and women must satisfy physiological and mental needs rather than social ones.

In the current situation, when movement and encounter with people are limited in Slovakia due to Covid-19, distance forms of assistance are preferred. Respondents turned to the distance form of crisis intervention of 131 respondents and used the distance form of crisis intervention programs. The most frequent helpline was the COVID helpline - related to the provision of information on illness, pandemic measures and assistance during illness, which was used by 131 respondents 52, another crisis helpline without mentioning 25 respondents, the social welfare office and the family helpline 22 respondents and the crisis helpline used 19. 
Since the onset of the pandemic until 30/03/2021, 9,624 cases of death from COVID-19 (Ministry of Health of the Slovak Republic, 2021) have been recorded in Slovakia, which only confirms that many families have needed to address the loss of a loved one. Domestic violence is one of the topics that have a high latency of reporting to experts and seeking help. Initiatives to stop violence and talk to women need to be supported. Based on the findings, we could state that helplines, crisis counselling and telephone forms of help are not sufficiently known to respondents. Rybanská gives us a different view of the situation. Based on an interview with her, we found out that their line turns to advise and help more than 100,000 young people and children every year. As Rybanská (2021) states: "On a daily basis, we deal with, roughly, 270 contacts, but the lack of funding precludes us from processing a further 200-300 calls on average. Currently, we employ a team of 60 professionally trained counsellors - psychologists, social workers, as well as special needs and therapeutical pedagogues who are trying to cover all the needs of our helpline, such that it can run nonstop 24/7" (Rybanská, personal communication, 2021). The problem is not the lack of general knowledge about the helpline but rather the lack of financial resources needed to expand the capacity of the helpline.

\section{Conclusion}

In accordance with the opinion of several authors (Buchanan, McConnell, 2016) within the cooperation of the employee with the client, it is important to get acquainted with the existence of social support of the client and use it to his advantage. Respondents preferred to talk to friends, followed by family, as a form of help, not to use any form of help, and as another option, they would download an expert after solving the problem. This finding corroborates the claim of Cimrmannová, who observes that a person experiencing crisis is most likely to seek help of their closest social circle - family members and friends (Cimrmannová et al, 2013). Based on the processed data of our research, the distance form of help, including telephone helplines and various online counselling centres, proves to be a little-sought option in cases where one cannot help oneself. Personal contact with an expert in the current social situation is not socially preferred, so it is necessary to inform society about the benefits of distance forms of crisis intervention as an effective tool in solving their personal problems. We consider various forms of advertising to be involved in projects where cooperation with other entities and valuable contact takes place as an effective tool for raising awareness of the existence of distance forms of crisis intervention; promotion through the media and social networks; annual activities for children and young people: "We run to help children!", project: "Let's read!"; cooperation with schools (Rybanská, personal communication, 2021). Let's not forget to provide comprehensive support for the lines. It does not have to be just a monetary gift, but also an award, a client's recommendation and involvement in their activities.

\section{References}

Buchanan, T. M., \& McConnell, A. R. (2016). Family as a source of support under stress: Benefits of greater breadth of family inclusion. Self and Identity, 16(1), 105, 97-122. doi:10.1080/15298868.2016.1226194

Bright, C. L. (2020). Social Work in the Age of a Global Pandemic, Social Work Research, Volume 44, Issue 2, June 2020, Pages 83-86, https://doi.org/10.1093/swr/svaa006

Cimrmannová, T. a kol. (2013). Krize a význam pomáhajících prvního kontaktu [Crisis and the importance of helping first contact]. Praha: Karolinum. 197.

IPčko. [cit. 2021-02-12]. Retrieved from https://ipcko.sk/

Law no. 448/2008 Coll SR of 30 October 2008 on social services and amending Act no. 455/1991 Coll. on Trades (Trade Act), as amended [Act of the National Council of the Slovak Republic no. 448/2008 Coll of the SR of 30 October 2008 on social services and amending and supplementing Act no. 455/1991 Coll. on Trade Licensing Trade]

Linka detskej istoty [Child Safety Line]. [cit. 2021-03-20] Retrieved from http://www.ldi.sk/koronavirus/

Ministry of Health of the Slovak Republic. Epidemiological situation]. (2021). 1-33. Retrieved from https://www.uvzsr.sk/docs/info/covid19/Epidemiologicka_situacia_210330.pdf

Puleo, S. \& McGlothlin, J. (2010) Overview of Crisis Intervention in Jackson-Cherry, L.-Erford.T.B.Crisis Intervention and Prevention. Pearson,1-24. Retrieved from https://ptgmedia.pearsoncmg.com/images/9780132431774/downloads/jackson_ch1_overviewofcrisisintervention.pdf Sá S.D, Werlang B.S, Paranhos M.E. (2008). Intervenção em crise [Crisis intervention]. Rev Bras Ter Cogn.4 (73-80). ISSN 1982-3746

Silva, J.A.M., Siegmund, G., \& Bredemeier, J. (2015). Crisis interventions in online psychological counselling. Trends in Psychiatry and Psychotherapy. 37(4), 171-182. 